\title{
Winckelmania: Hellenomania between ideal and experience
}

Book or Report Section

Accepted Version

Harloe, K. (2018) Winckelmania: Hellenomania between ideal and experience. In: Harloe, K., Momigliano, N. and Farnoux, A. (eds.) Hellenomania. British School at Athens - Modern Greek and Byzantine Studies. Taylor and Francis, Abingdon. ISBN 9781138243248 Available at https://centaur.reading.ac.uk/71772/

It is advisable to refer to the publisher's version if you intend to cite from the work. See Guidance on citing.

Publisher: Taylor and Francis

All outputs in CentAUR are protected by Intellectual Property Rights law, including copyright law. Copyright and IPR is retained by the creators or other copyright holders. Terms and conditions for use of this material are defined in the End User Agreement.

\section{www.reading.ac.uk/centaur}

\section{CentAUR}

Central Archive at the University of Reading 
Reading's research outputs online 


\section{Winckelmania}

\section{Katherine Harloe}

Eine denkende Seele kann am Strande des weiten Meers sich nicht mit niedrigen Ideen beschäftigen; der unermeßliche Blick erweitert auch die Schränken des Geistes, welcher sich anfänglich zu verlieren scheinet, aber grösser wiederum in uns zurück kommt.

A thinking soul on the shore of a vast sea cannot remain occupied with base ideas. The limitless prospect also broadens the confines of the spirit, which appears at first to lose itself, but which returns to us ennobled.

Winckelmann, Anmerkungen über die Geschichte der Kunst des Alterthums (1767), Vorrede

Man lernt nichts, wenn man ihn liest, aber man wird etwas.

One learns nothing when one reads him, but one becomes something.

Goethe, in Eckermann (1876) 235

Winckelmann was, of course, the most maniacal Hellenist of them all. As proof we have the testimony of one of the most original critics of his time. At the opening of the section on sculpture in his Salon of 1765, Denis Diderot paired Winckelmann with Jean-Jacques Rousseau as examples of a kind of non-violent fanatic with which he was familiar:

J'aime les fanatiques, non pas ceux qui vous présentent une formule absurde de croyance, et qui vous portant le poignard à la gorge, vous crient: Signe, ou meurs; mais bien ceux qui fortement épris de quelque goût particulier et innocent, ne voient plus rien qui lui soit comparable, le défendent de toute leur force; vont dans les maisons et les rues, non la lance, mais le sillogisme en arrêt, sommant et ceux qui passent et ceux qui sont arrêtés, de convenir de leur absurdité, ou de la supériorité des 
charmes de leur Dulcinée sur toutes les créatures du monde. Ils sont plaisans, ceux-ci. Ils m'amusent; ils m'étonnent quelquefois. Quand par hasard ils ont rencontré la vérité, ils l'exposent avec une énergie qui brise et renverse tout. Dans le paradoxe, accumulant images sur images, appelant à leur secours toutes les puissances de l'éloquence, les expressions figurées, les comparaisons hardies, les tours, les mouvemens; s'adressant au sentiment, à l'imagination, attaquant l'ame et sa sensibilité par toutes sortes d'endroits, le spectacle de leurs efforts est encore beau.

I'm fond of fanatics, not the ones who present you with an absurd article of faith and who, holding a knife to your throat, scream at you "Sign or die," but rather those who, deeply committed to some specific, innocent taste, hold it to be beyond compare, defend it with all their might, who go into street and household, not with a lance but with their syllogistic decree in hand, calling on everyone they meet either to embrace their absurd view or to avow that the charms of their Dulcinea surpass those of every other earthly creature. People like this are droll; they amuse me, sometimes they astonish me. When they've happened upon some truth, they advocate it with an energy that shatters and demolishes all before it. Courting paradox, piling image upon image, exploiting all the resources of eloquence, figurative expressions, daring comparisons, turns of phrase, rhythmic devices, appealing to sentiment, imagination, attacking soul and sensibility from every conceivable angle, the spectacle of their efforts is always beautiful. ${ }^{1}$

There is a certain paradox in Diderot's characterisation of his fanatical case-studies here. The criticisms are clearest in the case of Rousseau, whom Diderot teases for 'lash[ing] out against the literature he's cultivated all his life, the philosophy he himself professes, the society of our corrupt cities in the midst of which he burns to reside and whose acknowledgement, approbation, tribute he craves.' ('[I]1 se déchaîne contre les lettres qu'il a cultivées toute sa vie, la philosophie qu'il professa, la société de nos villes corrompues au milieu desquelles il brûle d'habiter, et où il seroit désespéré d'être ignoré, méconnu, oublié.' $)^{2}$ The paradoxes of Winckelmann's Hellenomania are less immediately apparent, and Diderot takes longer to develop them: 
'Tel est Winckelmann, lorsqu'il compare les productions des artistes anciens et celles des artistes modernes. Que ne voit-il pas dans ce tronçon d'homme qu'on appelle le Torse; les muscles qui se gonflent sur sa poitrine, ce n'est rien moins que les ondulations de flots de mer; ses larges épaules courbées, c'est une grande voûte concave qu'on ne rompt point, qu'on fortifie au contraire par les fardeaux dont on la charge. Et ses nerfs? les cordes des ballistes anciennes qui lançoient des quartiers de rochers à des distances immenses, ne sont en comparaison que des fils d'araignée. Demandes à cet enthousiaste charment, par quelle voie Glicon, Phydias et les autres sont parvenus à faire des ouvrages si beaux et si parfaits? Il vous répondra: Par le sentiment de la liberté qui élève l'ame, et lui inspire de grandes choses, les récompenses de la nation, la considération publique, la vue, l'étude, l'imitation constante de la belle nature, le respect de la postérité, l'ivresse de l'immortalité, le travail assidu, l'heureuse influence des moeurs et du climat, et le génie. Il n'y a sans doute aucun point de cette réponse qu'on osât contester. Mais faites-lui une seconde question, et demandez-lui s'il vaut mieux étudier l'antique que la nature, sans la connoissance, l'étude et le goût de laquelle les anciens artistes, avec tous les avantages particuliers dont ils ont été favorisés, ne nous auroient pourtant laissé que des ouvrages médiocres? L'antique, vous dira-t-il sans balancer, l'antique; et voilà tout d'un coup l'homme qui a le plus d'esprit, de chaleur et de goût, la nuit tout au beau milieu du Toboso.'

Such a one is Winckelmann when he compares the productions of ancient artists with those of modern artists. What doesn't he see in this stump of a man we call the Torso? The swelling muscles of his chest, they're nothing less than the undulations of the sea; his broad bent shoulders, they're a great concave vault that, far from being broken, is strengthened by the burdens it's made to carry; and as for his nerves, the ropes of ancient catapults that hurled large rocks over immense distances are mere spider-webs in comparison. Inquire of this charming enthusiast by what means Glycon, Phidias, and the others managed to produce such beautiful works and he'll answer you: by the sentiment of liberty which elevates the soul and inspires great things; by rewards offered by the nation, and public respect; by the constant observation, study, and imitation of the beautiful in nature, respect for posterity, intoxication at the prospect 
of immortality, assiduous work, propitious social mores and climate, and genius... There's not a single point of this response one would dare contradict. But put a second question to him, ask him if it's better to study the antique or nature, without the knowledge and study of which ancient artists, even with all the specific advantages they enjoyed, would have left us only mediocre works: The antique! he'll reply without skipping a beat -The antique! ... and in one fell swoop a man whose intelligence, enthusiasm, and taste are without equal betrays all these gifts in the middle of the Toboso. ${ }^{3}$

Diderot's amused characterisation of Winckelmann throws up many themes that are relevant not only to the latter's particular form of connoisseurship, but also to many of the eighteenthand nineteenth-century Hellenomanias that came in his wake. His commentary suggests three pairs of contrasting (one might even say conflicting) Winckelmanns, which draw out different interpretative possibilities inherent Winckelmann's work as well as reflecting attitudes that have played wider roles in shaping modern cultural responses to ancient Greek visual material.

\section{Classicism and historicism}

The first opposition - which might be thought to correspond roughly to that between Winckelmann as author of the Reflections on the Imitation of the Painting and Sculpture of the Greeks and that of the History of the Art of Antiquity - is classicism versus historicism. ${ }^{4}$ Diderot praises the historicist Winckelmann: the scholar who produces a narrative of the origins, growth, rise and fall of ancient art in its social, cultural and political contexts. But the classicising Winckelmann, who 'compares the productions of ancient artists with those of modern artists' and finds the latter wanting, is mocked..$^{5}$ This juxtaposition of two Winckelmanns (who cannot of course be separated in the neat manner I have just suggested) anticipates a tension that has shaped approaches to ancient Greek culture in the centuries since: the tension between treating ancient materials as a privileged source of aesthetic, moral 
or other values and a purportedly objective or non-judgemental approach which seeks to confine itself to interpreting that material within its original contexts.

\section{Verbal and visual}

Ich sehe in den mächtigen Umrissen dieses Leibes die unüberwundene Kraft des Besiegers der gewaltigen Riesen, die sich wider die Götter empöreten, und in den phlegraïschen Feldern von ihm erleget wurden: und zu gleicher Zeit stellen mir die sanften Züge dieser Umrisse, die das Gebäude des Leibes leicht und gelenksam machen, die geschwinden Wendungen desselben in dem Kampfe mit dem Achelous vor, der mit allen vielförmigen Verwandlungen seinen Händen nicht entgehen konnte.

In jedem Theile dieses Körpers offenbaret sich, wie in einem Gemählde, der ganze Held in einer besondern That, und man siehet, so wie die richtigen Absichten in dem vernünftigen Baue eines Pallastes, hier den Gebrauch, zu welcher That ein jedes Theil gedienet hat.

I see in the powerful contours of this body the invincible force of the conqueror of the mighty giants who rebelled against the gods and were laid low by him in the fields of Phlegra; and at the same time the soft features of this outline, which make the edifice of the body light and pliable, place before me its swift turns in the fight with Achelous, who, with all his various forms, could not escape the hero's hands.

Every part of this body reveals, as in a painting, the entire hero in a particular deed; and here one sees the use for which deed every part has served, just as one sees the suitable purposes in the rational construction of a palace. ${ }^{6}$ 
The second opposition concerns the distinction between the verbal and the visual, particularly with regard to the privileging of source material. It is no accident that Diderot chooses to characterise Winckelmann by referring to one of his most dense and allusive passages of prose poetry: the ekphrasis of the Belvedere Torso. Like his other famous statue descriptions, Winckelmann's Torso combines close observational detail with literary reference and is indebted to the literary form of ancient and Renaissance ekphasis. ${ }^{7}$ In the case of the Torso, Winckelmann's description conducts a circuit of the statue, describing and celebrating in turn its chest, left side, hips, back, and thighs, before returning to the left knee. It focuses throughout upon the sculptor's mastery of surface and contour, technical and aesthetic categories Winckelmann privileges in his more explicitly theoretical writings as 'distinguishing characteristics' ('Kennzeichen') of the highest style. ${ }^{8}$ Winckelmann's description is thus is clearly grounded in repeated, close observation of the statue itself and its comparison with the other monuments Winckelmann enjoyed the privilege of being able to study first-hand in Italy. ${ }^{9}$ Nevertheless, when it comes to interpreting the statue's iconography Winckelmann substitutes for this observational and comparative approach a learned flight of fantasy, alluding to mythical episodes known primarily through literary sources in order to ground his interpretation of it as the deified Herakles. ${ }^{10}$

This literary character of Winckelmann's statue interpretations that has led some scholars to criticise him for his overly literary approach towards the interpretation of Greek monuments; recently, however, Elizabeth Prettejohn has pointed out the continuing dependence of historians of art upon precisely the kinds of linkages Winckelmann makes and emphasised once more the status of his descriptions as 'distilled records of the process of looking and cogitation refined through his years of study. ${ }^{11}$ Here again we have a tension or oscillation in approaches to the interpretation of ancient objects, which is paraded in Diderot's comments on Winckelmann.

\section{Ideal and material}


The third thematic contrast introduced by Diderot's characterisation is that between the ideal and the material. There are several different senses in which the concept of ideal is relevant to Winckelmann's work. An important one is his cleaving to the aesthetics of the beau idéal: the notion that art aims at imitation of a perfected or spiritualised nature and that the end of interpretation (viewing) is likewise appreciation of the idealised conception that existed in the mind of the artist. This is surely is one of the reasons for Diderot's decision to juxtapose Winckelmann with Rousseau: the fanatical defender of the beau idéal against the equally fanatic defender of la nature. Potts highlights a different sense of ideality at work in Winckelmann's writings when he comments that 'It is striking how in Winckelmann, the materiality of the antique nude seems to have so little to do with its materiality as a work of art. The physical sensuous aspect of a sculpture is defined almost exclusively in terms of the body it represents, rather than the literal substance of the sculptural object itself.' ${ }^{12}$ What Potts means may perhaps be revealed by considering a passage from the History of Ancient Art in which Winckelmann comments upon the Laocoön:

Die äußerste Haut dieser Statuen, welche gegen die geglättete und geschliffene etwas rauchlich scheinet, aber wie ein weicher Sammt gegen einen glänzenden Atlas, ist gleichsam wie die Haut an den Körpern der alten Griechen, die nicht durch beständigen Gebrauch warmer Bäder, wie unter den Römern bey eingerissener Weichlichkeit geschah, ausgelöset, und durch Schabeeisen glatt gerieben worden, sondern auf welche eine gesunde Ausdünstung, wie die erste Anmeldung zur Bekleidung des Kinns, schwamm.

The outermost skin of this statue, which appears somewhat rough when compared with a smoothed and polished surface, albeit like a soft velvet when compared with a lustrous satin, is, as it were, like the skin on the bodies of the ancient Greeks, which had not been loosened by the constant taking of warm baths, as was the case with the Romans among whom softness prevailed, and by being rubbed smooth with a scraper but on which swam a wholesome perspiration, like the first down on the chin. ${ }^{13}$ 
Despite the appreciation of the materiality of surface revealed in the comparison of velvet and satin, there is a sense in which Winckelmann directs our attention not to the Laocoön but through it, to his reconstructed, idealised and fantastical world of athletic and wholesome Greek male bodies exercising naked under the Attic sun. This is one way in which Diderot's characterisation of Winckelmann as quixotic seems apposite: a charge picked up by other eighteenth-century commentators on Winckelmann's approach to Greek art. For Christian Gottlob Heyne, for example, it was again Winckelmann's statue descriptions that reminded him of Cervantes' antihero:

Wir haben die vortrefflichste Beschreibung des Laocoon von unserm Winkelmann, welche nur die Begeisterung eingeben konnte, und die wiederum ihrer Seits Begeisterung mitzutheilen dienen kann: sie hier zu wiederholen wäre unnöthig; allein, einen deutlichen Begriff und Vorstellung von der Gruppe zu geben, ist sich nicht entworfen: und man muß diese Figur schon genau kennen und überdacht haben, ehe jene Beschreibung ihre rechte Wirkung thun kann; sonst ist man in der Gefahr, in welche vor wenigen Jahren so viele unsrer jungen Landsleute zu gerathen pflegten, daß man sich, wie der Ritter von Mancha, in eine Entzückung und Begeisterung hineinarbeitet, wozu nichts weiter fehlt, als nur - ein wirklicher, oder doch ein bestimmter Gegenstand.

We have Winckelmann's excellent description of the Laocoon, which only enthusiasm could have produced and which in turn can only serve to convey enthusiasm. There is no need to reproduce it here, only to note that it is not composed so as to give a clear concept and idea of the group; one must already be well acquainted with this statue and have studied it before this description can have the correct effect; otherwise one runs the risk to which, a few years ago, so many of our young compatriots tended to succumb: that, like the knight of La Mancha, one works oneself into a state of rapture and enthusiasm to which nothing is lacking except for an actual, or at least a determinate, object. ${ }^{14}$ 
Heyne's comments express his exasperation with the trend for enthusiastic yet unscholarly description to which, as he also complains elsewhere, Winckelmann's writings had given birth. ${ }^{15}$ Yet his criticisms also testify as to how Winckelmann's descriptions are evocative to a degree that is virtually unparalleled in the scholarly literature before or since. This is because they purport to record and/or encourage a mode of experience of ancient objects that is predicated on both close observation and imagination, that is claimed to elevate the viewer both sensually and intellectually, to render cognitive and historical insight but also to be based on emotional and indeed physical response. This is what Diderot has in mind when he talks of the assault upon the soul and sensibility presented by both Winckelmann's and Rousseau's writings, which renders their fanaticism beautiful and astonishing and attracts acolytes.

\section{Winckelmania}

It is this kind of experience in the presence of the work of art that I would characterise as a distinctively 'Winckel-mania', and it is my contention that it was as significant to the ways in which ancient Greek material culture was received in the eighteenth and nineteenth centuries as Winckelmann's more readily recognizable theoretical formulations, such as the notion of four period styles or the idea of liberty as the cause of artistic greatness. The Winckelmaniac experience of ancient objects is, perhaps, harder to distinguish, not least because it lies within a larger set of rapturous or reverent encounters with Greek (and, for that matter, Roman) antiquities with which we are familiar. There is, of course, the longer humanistic tradition of conversing with the ancients as dead souls or ghosts: imaginatively summoning the spirits of past souls to one's study for late-night conversation (Machiavelli, Plato). And the eighteenth and nineteenth centuries are also full of instances of imaginative or nostalgic encounters with antiquity 'on the ground', which form an inspiration to artistic, literary or theoretical production: one might think, for example, of Edward Gibbon's famous 'Capitoline Vision', William Beckford's and Percy Shelley's 'reveries' at Pompeii, or the meditations on meditations on temporality and decay prompted Benjamin West's and Wilhelm von Humboldt's first sights of Rome). ${ }^{16}$ 
These earlier and contemporary flights of fantasy differ from Winckelmania in a number of ways: most obviously, in that they tend to occur to the artist or writer when he is contemplating an entire vista or architectural prospect, rather than a discrete object such as a particular statue. Another divergence, which reveals the long genealogy of this trope stretching back before the bifurcation of 'classical antiquity' into Greek and Roman periods, as well as the realities of travel for many in the early modern period, is that they seem to be prompted by contemplation of Rome more often than of Greece (although it should be remembered that many of the artworks that most fired Winckelmann's imagination turned out to be Greco-Roman rather than Greek, and that sites in Magna Graecia such as Paestum or Pompeii furnished material ripe for Hellenomaniac fantasy). There is, moreover, a significant difference in the character of the experience itself. For Gibbon or Humboldt, the feelings that arose upon Italian soil provided a prompt to further scholarship or study. For Winckelmann and his followers, seeing the ancient object is experienced as epistemically valuable in itself: enthusiasm is considered as a means of gaining knowledge about a particular ancient object or about the ancient past more generally. This knowledge is, moreover, considered to be an ethically transformative or uplifting experience for the viewer. This is perhaps why Winckelmania tends to attach to Greek objects (or at least, objects believed to be Greek) more often than Roman ones, and it is no accident that several of Winckelmann's descriptions culminate with first-person reference to the observer as an 'I' who is ennobled and transformed in this rapturous encounter with the object:

Durch eine geheime Kunst aber wird der Geist durch alle Thaten seiner Stärke bis zur Vollkommenheit seiner Seele geführet, und in diesem Stücke ist ein Denkmahl derselben, welches ihm kein Dichter, die nur die Stärke seiner Arme besingen, errichtet: der Künstler hat sie übertroffen. Sein Bild des Helden giebt keinem Gedanken von Gewaltthätigkeit und ausgelassener Liebe Platz. In der Ruhe und Stille des Körpers offenbaret sich der gesetzte große Geist; der Mann, welcher den Dichtern ein Beyspiel der Tugend geworden ist, der sich aus Liebe zur Gerechtigkeit den größten Gefährlichkeiten ausgesetzet, der den Ländern Sicherheit und den Einwohnern Ruhe geschaffet. 
By means of a secret art, however, the mind is led through all of the deeds of his strength up to the perfection of his soul, and in this work there is a monument to this very soul which no poet erects who sings only of the strength of his arms: the artist has surpassed it. His image of the hero gives no place to thoughts of violence and unruly love. In the peace and quiet of the body is revealed a calm, great spirit: the man who has become an example of virtue to the poets, who exposed himself to the greatest dangers from love of justice, who brought security to the nations and peace to the inhabitants. ${ }^{17}$

Ich vergesse alles andere über dem Anblicke dieses Wunderwerks der Kunst, und ich nehme selbst einen erhabenen Stand an, um mit Würdigkeit anzuschauen. Mit Verehrung scheint sich meine Brust zu erweitern und zu erheben, wie diejenigen, die ich wie vom Geiste der Weißsagung aufgeschwellet sehe, und ich fühle mich weggerückt nach Delos und in die Lycischen Hayne, Orte, welche Apollo mit seiner Gegenwart beehrete: denn mein Bild scheint Leben und Bewegung zu bekommen, wie des Pygmalions Schönheit. Wie ist es möglich, es zu malen und zu beschreiben.

In gazing up on this masterpiece of art I forget all else, and I myself adopt an elevated stance, in order to be worthy of gazing upon it. My chest seems to expand with veneration and to heave like those I have seen swollen as if by the spirit of prophecy, and I feel myself transported to Delos and the Lycian groves, places Apollo honoured with his presence - for my figure seems to take on life and movement, like Pygmalion's beauty. How is it possible to paint and describe it! ${ }^{18}$

The elevating effects of Winckelmaniac transport provide a particularly intense affirmation of the educative power of the (idealised) Hellenic. 
It is the prevalence of this form of experience - an apparently direct and transformative encounter with the ancient past which occurs via heightened experience of an object believed to be authentically ancient (most often, authentically Greek) - that I am interested in exploring. One reason why this might be useful is that a finer appreciation of Winckelmania may help us to understand the persistence of classicism into the 'romantic' era of the early nineteenth century. The basic puzzle here can be posed as the question of how far and in what ways romanticism supplants classicism, or how far classicism can be seen as living on in romanticism, albeit transformed. ${ }^{19}$ Foregrounding the fact that a component of eighteenthcentury classicism is the notion of gaining knowledge of antiquity via a particularly intense, individual experience of ancient objects may help us to understand this filiation. It also has the potential to expand our understanding of the content of neo-classicism beyond the imitation of classical forms and motifs, and therefore to forge new connections between different historical actors and kinds of material.

But trying to assess the prevalence of Winckelmania is not an easy task. For, quite apart from the aforementioned problem of distinguishing Winckelmania from other forms of humanistic and antiquarian reverie, it is far harder to reconstruct the character of historical actors' experiences than it is, say, to document the spread of Winckelmann's writings in publications across Italy, Germany, France and Amsterdam, and their translation into major European languages.

In the final part of this paper I present an example where I suspect that a distinctively Winckelmaniac experience is described. It is an eighteenth-century example, and from the Anglophone world. The eighteenth-century focus is dictated on the one hand by my particular expertise. On the other, my choice of an English writer is prompted by the particular interest offered by Anglophone receptions of Winckelmann, which have received relatively little attention compared to French, German, and Italian responses. ${ }^{20}$ It has sometimes been assumed that Winckelmann's influence on British Hellenism was mediated largely through the next generation of German poets and critics, especially Goethe and the Schlegel brothers. And it is certainly true that British writers show a stronger interest in Winckelmann from the mid-century onwards: an interest that begins from Pater's 
biographical essay (1867) and is continued through the work of writers such as Edward Carpenter and Oscar Wilde. ${ }^{21}$ Yet there was clearly some familiarity with Winckelmann's writings among the English reading public long before this. Although the History was not translated into English until the middle of the nineteenth century, Winckelmann's connoisseurial essays, the Letter on Herculaneum and Torso description were published in England (and in English translation) as early as the mid-1760s. ${ }^{22}$ Winckelmann's offices as a Vatican Library scriptor and as Papal Antiquarian and his service to Cardinal Albani, who served for a time as protector of British interests at Rome, placed him at the intersections of many social and political networks: connoisseurial, antiquarian, courtly and diplomatic. At Rome Winckelmann also encountered and socialised with younger and older artists and connoisseurs of various nationalities, from Anton Raphael Mengs to Sir William Hamilton, the Wortley Montagus and John Wilkes. In addition to the history of publication of and critical responses to Winckelmann's writings, therefore, we must add other channels of reception that are harder to trace: teacher-student and cicerone-tourist relations and networks of sociability (both face-to-face and in private correspondence). ${ }^{23}$

It is in relation to these more ephemeral kinds of encounter that I want to assess the example of Charles Burney. Perhaps best known now as the father of the important diarist and novelist, Fanny Burney, Charles was a literary figure in his own right who spent almost six months in Italy in 1770 in order to research his General History of Music (4 vols, 1776-89). His itinerary, which was typical of a Grand Tourist, included visits to Milan, Venice, Padua, Bologna, Florence and Naples, as well as two sojourns in Rome. The diary he kept is well known to eighteenth-century scholars as a valuable source of information on eighteenthcentury collections. It also provides fascinating testimony on the social dynamics of eighteenth-century learned tourism; for Burney's scholarly ambitions, as well as his entertainments, were furthered by a range of visitors and residents in the cities to which he travelled. Some, such as John Sackville, $3^{\text {rd }}$ Duke of Dorset, primarily provided hospitality; others, such as Sir William Hamilton, helped him gain access to collections he wished to study. Still others showed Burney around the sights. 
The first passage below records Burney's first visit to the Vatican collections on Saturday $22^{\text {nd }}$ September, around a week after his first arrival in Rome. After a hearty breakfast (a necessity for any self-respecting Englishman), he heads over to St Peter's in the party of his companions, 'Messrs Beckford and Vyse':

To describe what I saw or felt is equally impossible - all my great expectations were surpassed - the approach, the vestibula the grand scala - the mosaic - at the whole I was in a delirium. From hence to see the Apollo Belvedere - the Laocoon, the Antinous etc - all most exquisite - the very first statues in the universe!

Burney's description of his 'delirium' is brief, and a note of unintentional bathos is added by what follows straight afterwards: 'Dined very agreeably at the Duke of Dorset's'. ${ }^{24}$ As an account of a response to the Cortile Belvedere it is not very informative, but the phrase 'all my great expectations were surpassed' suggests, perhaps, that his response is predetermined: he sees something akin to what he expected see.

What had shaped and conditioned Burney's 'great expectations'? Various clues about this are scattered elsewhere in the diary. We might note, first, that his company on this visit includes 'Fuselier, the young artist' (not Johann Heinrich Füssli the painter and first English translator of Winckelmann's writings, but another Zürich native of the same name who had indeed associated with Winckelmann in Rome in the 1760s and eventually returned to Switzerland, where he became a historian and politician of some stature). ${ }^{25}$ Elsewhere in his diary Burney recounts visiting and conversing with other friends and former correspondents of Winckelmann, such as Mengs in Florence and Hamilton and Paderni in Naples. He is granted entry to the Vatican libraries by Cardinal Albani himself. What insights these men offered him during their conversations are left unrecorded, but it is not too fanciful to assume that these included recommendations on what to prioritise among Italy's many artistic treasures. 
It is above all the mode of Burney's recorded responses to particular sculptures, as much or more than the choices he makes about what to see, that suggest that he may have been something of a Winckelmaniac. Six days after his first, rapturous experience of the Vatican collections and in reward for a morning spent studying in the Vatican Libraries, he went on another aesthetic pilgrimage, once again accompanied by a resident guide, to the Capitoline Museum:

After dinner Captain Forbes played the cicerone and accompanied me to the Capitol or Campidoglio, where I saw so many fine remains of antiquity, it is impossible to remember half - tho' I confined myself to the statues only...

In the middle of the square is the finest equestrian statue in bronze of Marcus Aurelius, which has been preserved of ancient sculpture. The horse moves and the emperor speaks... I only went into the musaeum, or Palazzo de' Conservatore - at the entrance are 2 fine military statues of Julius Caesar, and Augustus after the battle of Actium. The feet and hand of the colossian Apollo brought by Lucullus from Pontus it was 41ft high so that the great toe is as thick as the body of the Abbe Grant, who is rather corpulent... The dying gladiator, one of the first statues in the world, finely preserved - Cupid and Psyche standing and kissing each other with innocent fondness his hand delicately supports her chin 'tis charming. Agripina, sedens to the last degree exquisite: such drapery and expression as I never saw in sculpture. Antonius [sic], by some preferred to that at the Belvedere... ${ }^{26}$

Burney begins his description from the equestrian statue of Marcus Aurelius. Although it is once again brief, his comment that 'The horse moves and the emperor speaks' is precisely the kind of taut, evocative comment we find time and time again in Winckelmann's writings. ${ }^{27}$ His singling out of the Agrippina's drapery and expression for particular praise makes casual reference to two connoisseurial categories Winckelmann had taken over from the French academic art tradition and extolled pointedly in relation to ancient sculpture in the Gedancken. It is interesting to see these categories applied in praise to a sculpture 
Winckelmann himself had criticised in the Geschichte as providing abundant evidence of the decline of art under Nero. ${ }^{28}$ The only explicit mentions of Winckelmann in Burney's travelogue are antiquarian in character, concerning his writings as a source of information about ancient musical instruments. ${ }^{29}$ Yet Burney's comments on sculpture hint at a rather looser Winckelmania of enraptured viewing practice, which conditioned (without fully determining) the choice of objects to privilege and was demonstrably linked to his predecessor by chains of international sociability and correspondence.

All this is highly tentative, but it poses the possibility that the link between Winckelmann's prostration before the Belvedere Apollo and Keats's 'sick' and 'dizzy pain' at the sight of the Elgin Marbles may be linked more closely than has hitherto been supposed. Despite the divergence (indeed, in some cases, the reversal) of critical judgements about specific ancient artworks evident between eighteenth- and nineteenth-century men of taste, some key components of Winckelmania - ideal, imaginary, edifying - have continued to inform both scholarly and more general cultural responses to ancient Greek material culture into the nineteenth and twentieth centuries, as successive generations have sought and found in ancient Greek their own image of 'Leben and Bewegung'. And, bringing with them such prejudices, each generation has run the danger of quixotism that Diderot and Heyne identified. This fact did not escape one nineteenth-century Hellenist who participated in Winckelmann's enthusiasm for Greece to a far greater degree than Diderot's detachment, despite his refusal to treat the Hellenic after the manner of Winckelmann as a principle of serenity and light:

Die Verehrung des klassischen Alterthums... das heisst also die einzig ernsthafte uneigennützige hingebende Verehrung, welche das Alterthum bis jetzt gefunden hat, ist ein grossartiges Beispiel der Don Quixoterie: und so etwas ist also Philologie besten Falls. So schon bei den alexandrinischen Gelehrten, so bei allen den Sophisten des ersten und zweiten Jahrhunderts, bei den Atticisten usw. Man ahmt etwas rein Chimärisches nach, und läuft einer Wunderwelt hinterdrein, die nie existirt hat. Es geht ein solcher Zug schon durch das Alterthum: die Art, wie man die homerischen Helden copirte, der ganze 
Verkehr mit dem Mythus hat etwas davon. Allmählich ist das ganze Griechenthum selber zu einem Objecte des Don Quixote geworden.

Reverence for classical antiquity... that is, the only serious, unselfserving, self-sacrificing reverence that antiquity has received to date, is a monumental example of Quixotism: and that is what philology is at best. So it was in the case of the Alexandrian scholars, so with all the sophists of the first and second centuries, with the Atticists, and so on. One imitates something that is purely chimerical, and chases after a wonderland that never existed. The same impulse ran through classical antiquity: the way in which the Homeric heroes were copied, the entire traffic with myth has something of this. Gradually, the whole of ancient Greece was made into an object worthy of Don Quixote. ${ }^{30}$

\footnotetext{
${ }^{1}$ Diderot (1960) 206; (1995) 156.

2 Diderot (1960) 206-7; (1995) 157.

${ }^{3}$ Diderot (1960) 207; (1995) 157.
}

${ }^{4}$ See Décultot (2000) for this mapping, which appears to be a pronounced trait of French-language receptions of Winckelmann.

${ }^{5}$ Diderot (1960) 207; (1995) 157.

${ }^{6}$ Winckelmann (2002) 170-1; English translation by Curtis Bowman in Winckelmann (2005) xiv-v, slightly modified.

${ }^{7}$ On the Torso description in particular and Winckelmann's ekphrastic practice in general, see Pfotenhauer (1995), Borg (1999), Giuliani (1999), Harloe (2007), Prettejohn (2012), Harloe (2013) 86-94, Vollhardt (2013) $177-81$.

${ }^{8}$ See especially the essays 'Erinnerung über die Betrachtung der Werke der Kunst' and 'Von der Grazie in Werken der Kunst“, first published in Bibliothek der schönen Wissenschaften und der freyen Künste in 1759 (Winckelmann (2002) 149-162. For discussion, see Harloe (2013) 70-77. These essays were likely composed while Winckelmann was making his study of the Stosch gem collection. Potts (1994) 84-9 conjectures plausibly that Winckelmann's emphasis upon contour, especially the 'Greek profile, as a mark of artistic greatness derives from his study of archaic Greek silver coins as 'the one solid empirical starting-point he had for tracing the early stylistic evolution of Greek art' (85). Coins and gems are reproduced as many of the head- and tailpieces of the Geschichte der Kunst des Alterthums, as well as the frontispiece of the 1763 Abhandlung von der Fähigkeit der Empfindung des Schönen in der Kunst, und dem Unterrichte in derselben.

${ }^{9}$ As Décultot (2000) 217-43 explores, the claim of authority based on his unprecedented and unrivalled opportunities for autopsy was one of the key means by which Winckelmann sought to differentiate himself from his predecessors and rivals. 
${ }^{10}$ See Borg (1999) for an alternative viewpoint.

${ }^{11}$ Prettejohn (2012) 78-9; for criticisms of the 'literariness' of Winckelmann's approach to ancient art see

Donohue (1995), Lolla (2002), and, albeit in a somewhat different vein, Himmelmann 1971.

${ }^{12}$ Potts (1994) 250.

${ }^{13}$ Winckelmann (1764) 253; (2006) 246.

${ }^{14}$ Heyne (1779) 18.

${ }^{15}$ Heyne (1778) vii-ix; see Potts (1978) 207.

${ }^{16}$ On Beckford see Baum 2011; on West see Galt (1960) 92-4. Humboldt's ruminations are reported by Goethe in his essay on Winckelmann: Goethe (1805) 408-9.

${ }^{17}$ Winckelmann (2002) 172; (2005) xvii.

18 Winckelmann (1764) 393; (2006) 334.

${ }^{19}$ See Jenkins (1992) 25.

${ }^{20}$ It is worth noting that Winckelmann's writings were disseminated in other European countries, and languages, considerably earlier than is often noted. Numerous French and Italian translations appeared between the 1760s and the 1780s (and some of Winckelmann's works were published originally in French or Italian). Lucy Russell, a doctoral researcher at the University of Oxford, is presently conducting research on Winckelmann's reception in Italy, 1755-1850.

${ }^{21}$ On Pater's essay, and the importance of Goethe within it, see Evangelista and Harloe (2017).

${ }^{22}$ Thoughts on the Imitation of the Painting and Sculpture of the Greeks, the response, Instructions to the Connoisseur and Essay on Grace, were published in the spring of 1766 as a subscription edition by Heinrich Fuseli. An English translation of Winckelmann's Torso description first appeared in the Annual Register for 1765 together with an abstract of the Herculaneum Letter, an English translation of which (from the French) appeared in 1771. French translations of Winckelmann's History advertised by London booksellers as early as 1766.

${ }^{23}$ For a discussion of some of the young men to whom Winckelmann acted as cicerone and with whom he struck up friendships, see Morrison (1996). The fundamental study of Winckelmann's correspondence is Disselkamp (1993).

${ }^{24}$ Burney (1969) 130-1.

${ }^{25}$ Pop (2015) 13.

${ }^{26}$ Burney (1969) 137.

${ }^{27}$ Compare, for example, Winckelmann's famous characterisation of the female painted dancers from Herculaneum as 'flüchtig wie ein Gedanke, und schön wie von der Hand der Gratien ausgeführet' ('fleeting as a thought and beautiful as if they were drawn by the Graces') Winckelmann (1762) 30; (2011) 83.

${ }^{28}$ Winckelmann (1764) 395-6; (2006) 335. In fact, Winckelmann also comments on the smooth finish of the fragments of the colossal 'Apollo' (in truth a statue of Constantine I) in implicitly disapproving terms: 'Die Coloßische Statue aber, von welcher im Campidoglio beyde Füße, Stücke von den Armen, und eine Kniescheibe übrig sind (die von dem Colossus des Apollo, welchen Lucullus aus Apollonien nach Rom führete, seyn sollen, war geschliffen und gegleitet.' ('[T]he fragments of the colossal statue on the Campidoglio - consisting of both feet, parts of the arms, and a kneecap, which are said to be from the colossus of Apollo that [Marcus] Lucullus 
carried to Rome from Apollonia [(Sozopol, Bulgaria)] - were smoothed and polished' (Winckelmann (1764)

234-5; (2006) 246-7). For the identification as Constantine I see Borbein, Kunze et al. (2006) 322.

${ }^{29}$ Burney (1969) 148 (perhaps significantly in the context of a visit to the Villa Albani), 171.

${ }^{30}$ Nietzsche (1998) 8.121; English translation modified and expanded from Porter (2008) 476.

\section{References}

Baum, C. (2011) 'Ruined Waking Thoughts: William Beckford as a Visitor to Pompeii', in Hales, S. and Paul, J. (eds) Pompeii in the Public Imagination from its Rediscovery to Today, Oxford: Oxford University Press, 34-47.

Borbein, A., Kunze, M., et al., (eds) (2006) Johann Joachim Winckelmann: Geschichte der Kunst des Alterthums. Katalog der Denkmäler, Mainz: Philipp von Zabern.

Borg, B. E. (1999) 'Allegorie der Kunst - Kunst der Allegorie. Winckelmanns „Kunstbeschreibungen“ also archäologischer Kommentar’ in Most, G. W. (ed.) Commentaries-Kommentare, Göttingen: Vandenhoeck and Ruprecht, 282-95

Burney, C. (1969) Music, Men and Manners in France and Italy 1770... , ed. Poole, H.E., London: Folio Society.

Diderot, D. (1960) Salons Volume II: 1765, ed. Seznec, J. and Adhémar, J., Oxford: Clarendon.

Diderot, D. (1995) Diderot on Art - 1: The Salon of 1765 and Notes on Painting, tr. Goodman, J., New Haven and London: Yale University Press.

Disselkamp, M. (1993) Die Stadt der Gelehrten. Studien zu Johann Joachim Winckelmanns Briefen aus Rom, Berlin: Walter de Gruyter.

Donohue, A. A. (1995) 'Winckelmann's History of Art and Polyclitus' in Moon, W.G. (ed), Polykleitos, the Doryphoros, and Tradition, Madison: University of Wisconsin Press, 327-53.

Eckermann, J.P. (1876) Gespräche mit Goethe, 4th edn, Volume I, Leipzig: Brockhaus 1876. 
Evangelista, S., and Harloe, K. (2017) 'Pater's 'Winckelmann': Aesthetic Criticism and Classical Reception', in Martindale, C., Evangelista, S., and Prettejohn, E. (eds), Pater the Classicist: Classical Scholarship, Reception, and Aestheticism, Oxford: Clarendon.

Galt, J. (1960) The life, studies, and works of Benjamin West, Esq. President of the Royal Academy of London, Gainsville: Scholars' facsimiles and reprints.

Giuliani, L. (1999) 'Winckelmanns Laokoon: von den befristeten Eigenmächtigkeit des Kommentars', in Most, G.W. (ed.), Commentaries - Kommentare. Göttingen: Vandenhoeck and Ruprecht, 296-322.

Goethe, J.W. (ed.) (1805) Winkelmann und sein Jahrhundert: in Briefen und Aufsätzen. Tübingen.

Harloe, K. (2007) 'Allusion and Ekphrasis in Winckelmann's Paris Description of the Apollo Belvedere', Cambridge Classical Journal 53, 229-52.

Harloe, K. (2013) Winckelmann and the Invention of Antiquity: History and Aesthetics in the Age of Altertumswissenschaft, Oxford: Clarendon.

Heyne, C.G. (1778) Sammlung antiquarischer Aufsätze, Vol. I, Leipzig: Weidmann.

Heyne, C. G. (1779) 'Prüfung einiger Nachrichten und Behauptungen vom Laocoon im Belvedere', Sammlung antiquarischer Aufsätze, Vol. II, 1-52, Leipzig: Weidmann.

Lolla, M.G. (2002) 'Monuments and Texts: Antiquarianism and the Beauty of Antiquity', Art History 25.4: 431-49.

Morrison, J. (1996) Winckelmann and the Notion of Aesthetic Education, Oxford: Clarendon.

Nietzsche, F.N. (1988) Sämtliche Werke. Kritische Studienausgabe in 15 Einzelbänden, ed. Colli, G., and Montinari, M., 2nd edn, 15 vols, Munich: Deutscher Taschenbuch Verlag.

Pfotenhauer, H. (1995) 'Winckelmann und Heinse. Die Typen der Beschreibungskunst im 18. Jahrhundert oder die Geburt der neueren Kunstgeschichte', in Boehm, G. and Stierle, K. (eds), Beschreibungskunst-Kunstbeschreibunt. Ekphrasis von de Antike bis zur Gegenwart, Munich: Wilhelm Fink, 313-40. 
Porter, J. I. (2008) 'Reception Studies: Future Prospects', in Hardwick, L. and Stray, C. (eds), A Companion to Classical Receptions, Oxford: Blackwell, 469-81.

Potts, A. (1978) 'Winckelmann's History of Art in its Eighteenth-Century Context', Ph.D. thesis, Warburg Institute, University of London.

Potts, A. (1994) Flesh and the Ideal: Winckelmann and the Origins of Art History, New Haven and London: Yale University Press, 1994.

Prettejohn (2012) The Modernity of Ancient Sculpture: Greek Sculpture and Modern Art from Winckelmann to Picasso, London: I.B. Tauris.

Vollhardt, F. (2013) 'Laokoon, Aias, Philoktet. Lessings Sophokles-Studien und seine Kritik an Winckelmann,' in Robert, J. and Vollhardt, F. (eds), Unordentliche Collectanea. Gotthold Ephraim Lessings Laokoon zwischen antiquarischer Gelehrsamkeit und ästhetischer Theoriebildung, Berlin: De Gruyter,175-200.

Winckelmann, J. (1762) Sendschreiben von den Herculanischen Entdeckungen..., Dresden: Walther.

Winckelmann, J. (1764) Geschichte der Kunst des Alterthums, Dresden: Walther.

Winckelmann J. (1767), Anmerkungen über die Geschichte der Kunst des Alterthums, Dresden: Walther

Winckelmann, J. (2002) Kleine Schriften, Vorreden, Entwürfe, ed. Walther Rehm. Berlin and New York: Walter de Gruyter.

Winckelmann, J. (2005) Description of the Torso in the Belvedere in Rome, Essay on the Capacity for the Sentiment for the Beautiful in Art, Reflections on the Painting and Sculpture of the Greeks, tr. Curtis Bowman and Henry Fuseli, ed. Curtis Bowman, New York and London: Continuum.

Winckelmann, J. (2006) History of the Art of Antiquity, tr. H. F. Mallgrave, introduction by Alex Potts, Los Angeles: Getty Research Institute.

Winckelmann (2011) footnote no. 27 = not found in bibliography 